Article

\title{
Quality and Nutritional Evaluation of Regina Tomato, a Traditional Long-Storage Landrace of Puglia (Southern Italy)
}

\author{
Massimiliano Renna ${ }^{1,2}$, Miriana Durante ${ }^{3}$, Maria Gonnella ${ }^{1, *}$, Donato Buttaro ${ }^{1}$, \\ Massimiliano D'Imperio ${ }^{1}$, Giovanni Mita ${ }^{3}$ and Francesco Serio ${ }^{1, *}$ \\ 1 Institute of Sciences of Food Production (ISPA), CNR, via Amendola 122/O, 70126 Bari, Italy; \\ massimiliano.renna@uniba.it (M.R.); donato977@gmail.com (D.B.); \\ massimiliano.dimperio@ispa.cnr.it (M.D.) \\ 2 Department of Agricultural and Environmental Science, University of Bari Aldo Moro, \\ via Amendola 165/A, 70126 Bari, Italy \\ 3 Institute of Sciences of Food Production (ISPA), CNR, via Lecce-Monteroni, 73100 Lecce, Italy; \\ miriana.durante@ispa.cnr.it (M.D.); giovanni.mita@ispa.cnr.it (G.M.) \\ * Correspondence: maria.gonnella@ispa.cnr.it (M.G.); francesco.serio@ispa.cnr.it (F.S.); \\ Tel.: +39-080-5929306 (M.G.); +39-080-5929313 (F.S.)
}

Received: 10 May 2018; Accepted: 11 June 2018; Published: 13 June 2018

\begin{abstract}
Regina tomato, a locally cultivated Italian landrace, is listed as an item in the 'List of Traditional Agri-Food Products' of the Italian Department for Agriculture and itemised as 'Slow Food presidium' by the Slow Food Foundation. It is classified as a long-storage tomato since it can be preserved for several months after harvest thanks to its thick and coriaceous skin. Three ecotypes were investigated for main physical and chemical traits both at harvest and after three months of storage. Experimental results indicate that this tomato landrace has a qualitative profile characterized by high concentrations of tocopherols, lycopene and ascorbic acid (maximum 28.6 and $53.7 \mathrm{mg} / \mathrm{kg}$ fresh weight, $\mathrm{FW}$, and $0.28 \mathrm{mg} / \mathrm{g} \mathrm{FW}$, respectively) even after a long storage time, together with lower average Total Soluble Solids. The initial and post-storage contents of the bioactive compounds changed at a different rate in each ecotype (i.e., in Monopoli Regina tomato the highest content of $\alpha$-Tocopherol, thereafter reduced to the same level of the other two ecotypes). These results indicate unique and unmistakable features of this long-storage tomato, closely linked to the geographic origin area that include both natural (available technical inputs) and human (specific cultural practices) factors.
\end{abstract}

Keywords: ecotypes; geographical origin area; HPLC analyses; long storage time; Solanum lycopersicum L.; heirloom

\section{Introduction}

Tomato (Solanum lycopersicum L.) is a species of great economic importance, which is widely cultivated all over the world. It offers beneficial effects to human health through its high content in potassium and antioxidants such as ascorbic acid, vitamin A, lycopene and tocopherols [1]. Tomato was introduced from America to Europe at the beginning of the Sixteenth century with greater success especially in the Mediterranean countries [2]. In Italy, this species found a secondary centre of diversification, since several landraces developed in different regions as a consequence of the adaptation to different environmental and cultivation conditions [3]. This allowed the diffusion of different fruit typologies such as flat, angled, ribbed, pear-shaped, heart-shaped, elongated as well as oval/round, cherry and plum forms [2,4]. 
Puglia, located in the southern part of Italy, can be considered a region placed in the centre of the Mediterranean basin [5]. With a long tradition in vegetable growing, this region is particularly rich in tomato landraces obtained by farmers themselves after repeated simple selection procedures generation after generation. It is important to highlight that a landrace, also called local variety, farmer's variety, folk variety, is a population of a crop characterized by greater or lesser genetic variation, which is however well identifiable and which usually has a local name [6].

Regina is the name of a tomato landrace grown in the coastal saline soils of the central Puglia. This landrace takes its Italian name, Regina (Italian for "Queen"), from its calyx (Figure 1A), which takes the shape of a crown as it grows. It is listed as an item in the 'List of Traditional Agri-Food Products' of the Italian Department for Agriculture, since its processing, preservation and ageing methods are consolidated in time, harmonious for all the region involved, according to traditional rules, for a period not less than 25 years. Moreover, this landrace is registered also as 'Slow Food presidium' by the Slow Food Foundation [7] that aims to protect authenticity and origin of Italian traditional food products by valorising a geographical area and stimulating market opportunities.

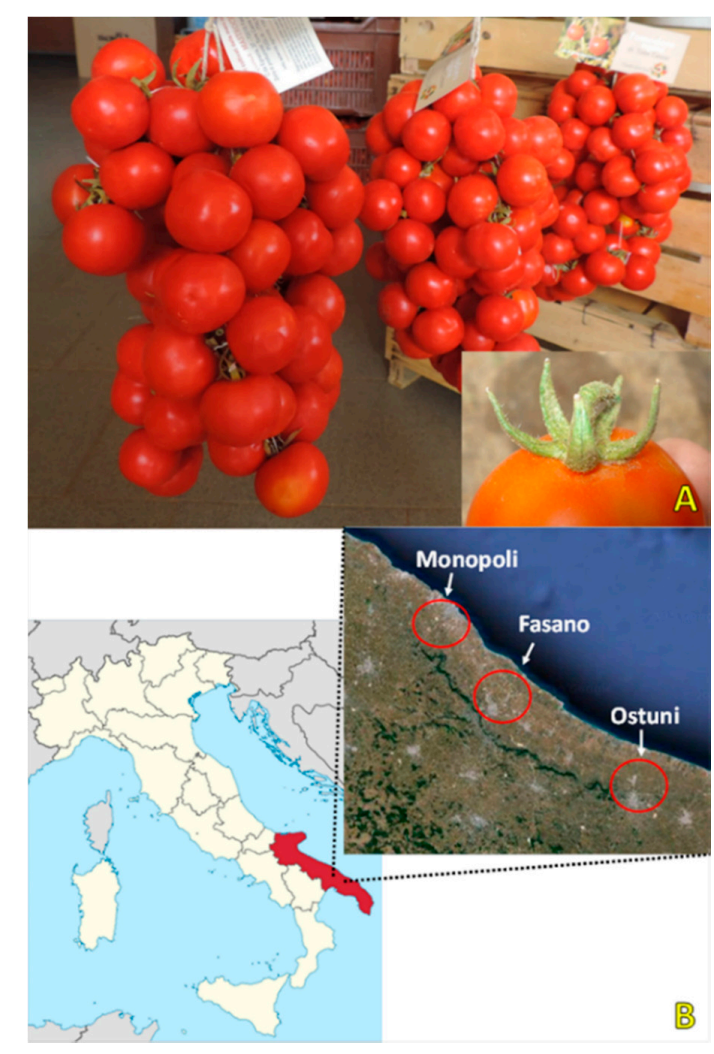

Figure 1. Bunches, so-called ramasole, of Regina tomato with a focus on the fruits calyx (A); map of Italy with Puglia region (highlighted in red) and a focus of the three sites (within the circle) where the Regina tomato ecotypes were cultivated and collected (B).

The Regina tomato (RT) fruits are small and rounded with a thick skin which improves the resistance to parasites as well as the post-harvest preservation. There is a local tradition of braiding tomatoes in bunches so-called ramasole, by tying the peduncles together with a cotton thread (Figure 1A). The original seed of RT was jealously preserved and reproduced each year by local farmers, who continued to grow it in traditional orchards, even intercropping tomatoes with olive or cotton, as reported by the local history [7]. The hot-arid conditions of the local environment favoured the adaptation of this landrace to the scarcity of the natural resources. So, RT plants are generally grown without irrigation, or with sporadic supplemental irrigation by using brackish water coming 
from aquifers. This agronomical practice favours the obtaining of tasty tomato fruits very appreciated by local consumers.

RT is locally classified as pomodoro da serbo, in English long-storage tomato, that is a typical southern Italy type of tomato, characterized by small size fruits (i.e., high skin/volume ratio), with thick and coriaceous skin, low water content and rich in bioactive compounds concentrated in the epicarp and mesocarp $[4,8,9]$. Its fruits are stored in typical hanged crowns for six months [6]. So, a peculiarity of RT is that the ramasole can be preserved for several months ensuring availability of this kind of tomatoes in the winter months. Nevertheless, over the last 20 years, the cultivation of this local variety has gradually diminished due to the advent of greenhouse production that brings cherry tomatoes on the market all the year-long.

A recent and remarkable study defines a thorough nutritional profile of several long storage tomato genotypes retrieved in different area of Southern Italy [10]. Studies are available for other tomato landraces of different geographical areas [1,2,11,12], but literature lacks information on RT, a landrace of an unreported geographical area. Starting from these remarks, the aim of the present study was to evaluate the main physical and chemical traits of this heirloom tomato at harvest and after three mounts of storage, simulating the long storage of the ramasole. The general goal was to assess quality and nutritional traits of RT and promote its diffusion in the market as a regional origin food product recognized by specific marks such as the Protected Designation of Origin (PDO) and the Protected Geographical Indication (PGI).

\section{Materials and Methods}

\subsection{Location and Cropping Details}

Three RT ecotypes were open field cultivated on local private farms by using local cultivation practices. Each ecotype was cultivated inside the area where it has been selected: Monopoli $\left(40^{\circ} 55^{\prime} 40.8^{\prime \prime}\right.$

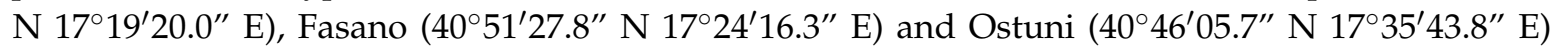
(Figure 1B), since each ecotype is characterized by a specific adaptation to the environmental and the cultivation conditions of the particular area where it has been selected. For this reason, each ecotype has a local name that corresponds to the name of the cultivation site.

Seeds for crop propagation were self-produced and stored on-farm by each farmer. Transplanting was carried out at the four-leaf stage on 15 May for all sites. Plant density was 3.3 plants $/ \mathrm{m}^{2}$ and growing techniques were in line with the agricultural practices of local farmers specialized in growing this type of tomato. Plants were cultivated on silty-sandy soil, typical of the Puglia coastal areas, under the Mediterranean climate, with rain almost absent during the summer season and maximum temperatures sometimes approaching $30-35^{\circ} \mathrm{C}$ on the hottest days. So, supplemental irrigation was carried out, only as rescue irrigation after transplanting, for a total water amount of approximately $30 \mathrm{~mm}$ applied in one-two times, according to each site needs. Harvesting took place on 5 September for both sites when the proportion of ripe fruit reached about $95 \%$. At harvest tomato samples were refrigerated and then transported to the laboratory to be processed and analysed as described in the following sections.

\subsection{Physical Analysis}

For each site, three replications of RT fruits were collected for the physical analysis at harvest. So, on twenty fresh fruits for each replication, weight, polar and equatorial diameter, colour parameters and Total Soluble Solids (TSS) were measured.

After measurement of fruit sample fresh weight, the colour parameters, $L^{*}$ (lightness), $a^{*}$ (redness) and $b^{*}$ (yellowness) were measured in triplicate at five random points on the peel surface of the fruits with a colorimeter (CR-400, Konica Minolta, Osaka, Japan) in reflectance mode using the CIE $L^{*} a^{*} b^{*}$ colour scale. Before the measurements, the colorimeter was calibrated with a standard reference with $L^{*}, a^{*}$ and $b^{*}$ values of $97.55,1.32$ and 1.41 , respectively. Hue angle $\left(h^{\circ}=\tan ^{-1}\left[b^{*} / a^{*}\right]\right)$ and saturation or 
chroma $\left(C=\left[a^{* 2}+b^{* 2}\right]^{1 / 2}\right)$ were then calculated from the primary $L^{*}, a^{*}$ and $b^{*}$ readings. In addition, a Colour Index was calculated, according to the formula: Colour Index $=2000 \times a^{*} / L^{*} \times C$, together with the $a^{*} / b^{*}$ ratio [13].

The content of TSS, expressed in ${ }^{\circ}$ Brix, was measured using a refractometer (model DBR35, XS Instruments, Carpi, MO, Italy) on a liquid extract obtained by homogenizing $100 \mathrm{~g}$ of tomato fruits from each replication in a blender (Sterilmimex Lab., International PBI, Milan, Italy), and then filtering the juice.

\subsection{Samples Preparation for Chemical Analysis}

For chemical analysis RT fruits of each site were divided into two equal portions. One portion was stored at $4{ }^{\circ} \mathrm{C}$ for 96 days, while the other portion was analysed as fresh samples. For each treatment three replications were prepared for obtaining a total of 18 samples ( 3 ecotypes $\times 2$ storage times $\times$ 3 replications). One part of each replication was dried in a forced air oven at $105{ }^{\circ} \mathrm{C}$ until reaching a constant mass for the determination of the dry weight (DW) content. Results were expressed as $\mathrm{g} / 100 \mathrm{~g}$ fresh weight (FW). The other half portion was lyophilized by using a laboratory freeze-dryer (LABCONCO FreeZone ${ }^{\circledR}$ Freeze Dry System, model 7754030, Kansas City, MI, USA) equipped with a stoppering tray (LABCONCO FreeZone ${ }^{\circledR}$ Stoppering Tray Dryer, model 7948030, Kansas City, MI, USA). The freeze-dried matter was ground at $500 \mu \mathrm{m}$ by using a laboratory mill (Retsch Italia s.r.l., Torre Boldone, BG, Italy) to obtain a homogeneous powder.

\subsection{Isoprenoids Analysis}

Triplicate aliquots of freeze-dried tomato powder were used to extract isoprenoids (carotenoids and tocopherols) by the method of Sadler et al. [14] modified by Perkins-Veazie et al. [15]. HPLC analyses were carried out using an Agilent 1100 Series HPLC system as described by Fraser et al. [16]. Isoprenoids were separated using a reverse-phase C30 column $(5 \mu \mathrm{m}, 250 \times 4.6 \mathrm{~mm})$ (YMC Inc., Wilmington, NC, USA) with mobile phases consisting of methanol (A), $0.2 \%$ ammonium acetate aqueous solution/methanol (20:80 v/v) (B), and tert-methyl butyl ether (C). The isocratic elution was as follows: $0 \mathrm{~min}, 95 \% \mathrm{~A}$ and $5 \% \mathrm{~B} ; 0$ to $12 \mathrm{~min}, 80 \% \mathrm{~A}, 5 \% \mathrm{~B}$, and $15 \% \mathrm{C} ; 12$ to $42 \mathrm{~min}, 30 \%$ $\mathrm{A}, 5 \% \mathrm{~B}$, and $65 \% \mathrm{C} ; 42$ to $60 \mathrm{~min}, 30 \% \mathrm{~A}, 5 \% \mathrm{~B}$, and $65 \% \mathrm{C} ; 60$ to $62 \mathrm{~min}, 95 \% \mathrm{~A}$, and $5 \% \mathrm{~B}$. The column was re-equilibrated for $10 \mathrm{~min}$ between runs. The flow rate was $1.0 \mathrm{~mL} / \mathrm{min}$, and the column temperature was maintained at $25^{\circ} \mathrm{C}$. The injection volume was $10 \mu \mathrm{L}$. Absorbance was registered by diode array at wavelengths of $475 \mathrm{~nm}$ for carotenoids and $290 \mathrm{~nm}$ for tocopherols. Peaks were identified by comparing their retention times and UV-vis spectra to those of authentic standards. Tocopherols and carotenoid standards were purchased from Cayman chemicals (Ann Arbor, MI, USA) and CaroteNature (Lupsingen, Switzerland), respectively. The limit of detection was $0.4 \mathrm{mAU}$, tipically in the $2-10 \mathrm{ng} / \mathrm{g}$ range per compound. $\alpha$-Tocopherol (code 10007705) and B-tocopherol (code 46401-U) were purchased from Cayman chemicals (Ann Arbor, MI, USA) and Sigma Aldrich (Milan, Italy) respectively. Lutein (code 0133), $\alpha$-carotene, (code 0007), $\beta$-carotene (code 0003) and lycopene (code 0031) were purchased from CaroteNature (Lupsingen, Switzerland).

\subsection{Ascorbic Acid Determination}

The ascorbic acid content was evaluated using the method described by Ferreira et al. [17] with some modifications. Freeze-dried tomato samples $(0.1 \mathrm{~g})$ were extracted by $10 \mathrm{~mL}$ of $1 \%(w / v)$ metaphosphoric acid followed by shaking for $45 \mathrm{~min}$ at room temperature. The extract was centrifuged at $4000 \times g$ for $10 \mathrm{~min}$. The supernatant was collected and used for further analysis.

To $1 \mathrm{~mL}$ of supernatant, $9 \mathrm{~mL}$ of $0.005 \%$ 2,6-dichlorophenolindophenol (DCPIP) was added and the absorbance was measured within $30 \mathrm{~min}$ at $515 \mathrm{~nm}$ against a blank. The content of ascorbic acid was calculated on the basis of the calibration curve of authentic L-ascorbic acid $(25-250 \mu \mathrm{g} / \mathrm{mL}$; $\left.\mathrm{Y}=-0.0048 \mathrm{x}+1.2708, R^{2}=0.9994\right)$. 


\subsection{Glucose and Fructose Assay, and Sweetness Index}

Triplicate aliquots of freeze-dried tomato powder were used to determine glucose and fructose contents, by ionic chromatography (Dionex model DX500; Dionex Corp., Sunnyvale, CA, USA) according to protocols used by Caretto et al. [18]. Results were expressed as mg/g FW.

The sweetness index (SI) was calculated based on content and sweetness properties of individual carbohydrates by multiplying the sweetness coefficient of each sugar (glucose $=1.00$ and fructose $=2.30)$ by the concentration $(\mathrm{g} / 100 \mathrm{~g} \mathrm{FW})$ of that sugar in fruits [19].

\subsection{Starch Determination}

Starch content was determined by using Starch Assay Kit. The samples, $100 \mathrm{mg}$, were previous washed with aqueous ethanol, $10 \mathrm{~mL}(80 \% \mathrm{v} / \mathrm{v})$, incubated at $80-85^{\circ} \mathrm{C}$ for $5 \mathrm{~min}$ and stirred. After stir the samples were centrifugated for $10 \mathrm{~min}$ at $1800 \times g$ at room temperature, the supernatants were removed, and the samples were washed with aqueous ethanol $(80 \% v / v)$ for three different times, in order to remove the D-glucose. The pellets were used for quantification of starch in samples by using Megazyme kit total starch amyloglucosidase / $\alpha$-amylase (K-TSTA, Megazyme International Ltd. Wicklow, Bray, Ireland). For each treatment, triplicate extractions and analyses were carried out.

\subsection{Inorganic Cation Contents}

The content of $\mathrm{Na}^{+}, \mathrm{K}^{+}, \mathrm{Mg}^{2+}$ and $\mathrm{Ca}^{2+}$ was determined by ion exchange chromatography (Dionex DX120, Dionex Corporation, Sunnyvale, CA, USA) with a conductivity detector using an IonPac CG12A guard column and an IonPac CS12A analytical column (Dionex Corporation) as reported by D'Imperio et al. [20]. Results were expressed as mg/g FW.

\subsection{Statistical Analysis}

A two-way analysis of variance (ANOVA) was performed using the GLM procedure (SAS software, Version 9.1) applying a strip-plot design with storage time and site of cultivation as main factors for carotenoids, tocopherols, ascorbic acid, glucose and fructose content, dry matter and inorganic cations. For other quality traits a one-way ANOVA was performed considering only the ecotype. The separation of means was obtained by the Student-Newman-Keuls (SNK) test.

For a visual analysis of the data, Principal Component Analysis (PCA) (PROC PRINCOMP, SAS Software, Cary, NC, USA) was performed on previously mean-centred and standardised (unit-variance-scaled) data. The data matrix submitted to PCA was made up of six observations (two storage times and three sites of cultivation) and 17 parameters $\left(\mathrm{Na}^{+}, \mathrm{K}^{+}, \mathrm{Mg}^{2+}\right.$ and $\mathrm{Ca}^{2+}, \mathrm{DM}$, Glucose, Fructose, Glucose/Fructose ratio, Starch, Sweetness index, Lutein, $\alpha$-Carotene, $\beta$-Carotene, Lycopene, $\beta+\gamma$ tocopherol, $\alpha$-tocopherol, ascorbic acid). The PCA was applied to obtain an overview of the whole data variability simplified in a few main information. The results of the PCA are shown as biplots (XLStat, Addinsoft, Paris, France) of scores (storage time x ecotype) and loadings (variables).

\section{Results and Discussion}

\subsection{Physical Traits at Harvest}

RT fruits showed an average weight of about $22 \mathrm{~g}$ without any differences between the three ecotypes. At the same time, the average polar and equatorial diameter were, respectively, 29.9 and $34.5 \mathrm{~mm}$ without any differences between the three ecotypes (Table 1). On the other hand, TSS in Ostuni fruits were 9\% and 19\% higher than Monopoli and Fasano, respectively. These results suggest that different ecotypes did not affect form and size of the RT fruits, whereas TSS was influenced by different ecotypes as well as by environmental conditions. Moreover, these results are in according to some Authors $[8,21]$ who described fruits of long-storage tomatoes with an average weight of about $10-25 \mathrm{~g}$ and a form round or ellipsoid. It is interesting to highlight that form and size of RT are similar 
to "cherry tomato" fruits, considering that this type of tomato generally shows a diameter between 15 and $35 \mathrm{~mm}$ and an average weight between 10 and $30 \mathrm{~g}$ [21]. On the other hand, RT showed a lower TSS content respect to some cherry tomato types [21] as well as some landrace of Italian long-storage tomatoes such as "Montallegro" and "Filicudi" [22]). At the same time the TSS content of RT fruits results are similar to other Italian long-storage tomatoes such as "Albicocca di Favignana" and "Giallo piccolo a punta" [23] and other types of tomato including landraces and hybrids [2].

Regarding colour analysis, Monopoli fruits showed the highest lightness $\left(L^{*}\right)$, yellowness $\left(b^{*}\right)$, Hue angle $\left(h^{\circ}\right)$ and Chroma (C) value, while no difference between the ecotypes was found as regards redness $\left(a^{*}\right)$. No differences were found for $C$ between Ostuni fruits and those from Monopoli and Fasano. These results suggest that the colour of Fasano and Ostuni fruits may be perceived as more "red" than that of Monopoli fruits, according to Serio et al. [21] who described fruits of pomodoro da serbo with skin colour ranging from yellow to red. The colour index and $a^{*} / b^{*}$ ratio confirm this perception. Higher values of these two indices are assigned to redder and more mature tomato fruits with a prevalence of red colour [13,24]. In the case of RT fruits, lower values of $L^{*}$ and C in Fasano and Ostuni fruits influence the colour index values and differences in $\mathrm{b}^{*}$ values are determinant for the values of $a^{*} / b^{*}$ ratio (Table 1 ). Tomatoes are commonly selected by consumers on the basis of appearance, and colour is one of the most important quality factors that affect tomato appearance [25]. Tomato fruits are available in different external colours including pink, yellow, orange and red, as the result of both flesh and skin colours. Thus, a pink tomato may be due to colourless skin and red flesh, while an orange tomato may be due to yellow skin and red flesh [25]. RT fruits as well as other types of Italian long-storage tomatoes are characterized by the presence of a thick and coriaceous skin. Therefore, it is possible that the external colour of the RT fruits is strongly affected by their skin colour.

\subsection{Dry Matter and Inorganic Cation Contents}

The highest and the lowest values of dry matter were found in RT fruits after 96 days of storage, respectively, from Ostuni and Monopoli (Table 2). In Fasano fruits, the storage did not affect the dry matter content ( $7.18 \mathrm{~g} / 100 \mathrm{~g}$ FW on average). The increase of dry matter in Ostuni and Monopoli fruits can be due to water loss by transpiration and respiration during long-term storage [26]. Nevertheless, it is important to highlight that this increase of dry matter can be evaluated as marginal considering the long-term of storage. This is due to the presence of a coriaceous skin on pomodoro da serbo fruits, which strongly reduces the water evaporation and, therefore, favours a long storage period [21]. Baldina et al. [2] report a range of dry matter between 4.76 and $5.20 \mathrm{~g} / 100 \mathrm{~g}$ FW on fifteen Italian tomato landraces subjected to characterization. In a study aimed to evaluate the effects of watering regime on the quality of typical long-storage cherry tomatoes, Barbagallo et al. [23] report an average dry matter content between 5.92 and $7.34 \mathrm{~g} / 100 \mathrm{~g} \mathrm{FW}$, corresponding to watering regimes of $100 \%$ and $50 \%$, referring to the amount of water required to integrate plant evapotranspiration during growth. A high dry matter content in tomato fruits is considered as a good quality trait, and it is well known that a moderate water and/or salinity stress can increase dry matter in tomato fruits $[23,27]$. The results of the present study suggest that, independent of the ecotype, RT fruits showed a higher dry matter content compared to other types of long-storage tomatoes, highlighting an important good quality trait for the RT landrace. As regards the inorganic cation contents, only in the case of $\mathrm{Mg}^{2+} \mathrm{a}$ significant difference for the interaction between sites and storage time was found. The storage did not affect the $\mathrm{Mg}^{2+}$ content in Monopoli and Fasano fruits, whereas it caused an increase of about $18 \%$ in Ostuni. This is in agreement with the increase of the dry matter in Ostuni fruits as previously reported (Table 2). Magnesium is an important element for the human body: it is a cofactor for more than 300 enzymes and also has functions that affect nerve conduction [28]. On average, the $\mathrm{Mg}^{2+}$ content in RT fruits results are similar to what was reported by Chapagain and Wiesman [29] and by the United States Department of Agriculture for red tomatoes [30]. At the same time, RT fruits showed a higher and lower $\mathrm{Mg}^{2+}$ content as compared to orange and yellow tomatoes, respectively [30]. 
Table 1. Fruit weight, morphological traits, total soluble solids (TSS) and colour parameters of the Regina tomatoes at harvest.

\begin{tabular}{|c|c|c|c|c|c|c|c|c|c|c|c|c|}
\hline \multirow{2}{*}{ Ecotype } & \multirow{2}{*}{ Value } & \multirow{2}{*}{$\begin{array}{c}\text { Fruit } \\
\text { Weight (g) }\end{array}$} & \multicolumn{2}{|c|}{ Fruit Diameter $(\mathrm{mm})$} & \multirow{2}{*}{$\begin{array}{c}\text { TSS } \\
\left({ }^{\circ} \text { Brix }\right)\end{array}$} & \multirow{2}{*}{$L^{*}$} & \multirow{2}{*}{$a^{*}$} & \multirow{2}{*}{$b^{*}$} & \multirow{2}{*}{$h^{\circ}$} & \multirow{2}{*}{ C } & \multirow{2}{*}{$\begin{array}{l}\text { Colour } \\
\text { Index }\end{array}$} & \multirow{2}{*}{$a^{*} / b^{*}$} \\
\hline & & & Pol & Equ & & & & & & & & \\
\hline \multirow{2}{*}{ Monopoli } & Mean & 21.5 & 30.0 & 34.8 & $7.0 \mathrm{~b}$ & $47.0 \mathrm{a}$ & 32.2 & $41.0 \mathrm{a}$ & $51.7 \mathrm{a}$ & $52.3 \mathrm{a}$ & $26.5 \mathrm{~b}$ & $0.8 \mathrm{~b}$ \\
\hline & SD & 3.7 & 2.1 & 1.9 & 0.3 & 2.7 & 3.0 & 4.4 & 5.2 & 2.3 & 4.5 & 0.2 \\
\hline \multirow{2}{*}{ Fasano } & Mean & 20.1 & 29.4 & 34.0 & $6.4 \mathrm{c}$ & $40.0 \mathrm{~b}$ & 32.3 & $30.3 \mathrm{~b}$ & $43.1 \mathrm{~b}$ & $44.4 \mathrm{~b}$ & $36.6 \mathrm{a}$ & $1.1 \mathrm{~b}$ \\
\hline & SD & 3.3 & 1.5 & 2.1 & 0.1 & 2.8 & 4.3 & 4.6 & 1.9 & 6.1 & 3.2 & 0.1 \\
\hline \multirow[b]{2}{*}{ Ostuni } & Mean & 25.0 & 30.2 & 34.8 & $7.6 \mathrm{a}$ & $38.1 \mathrm{~b}$ & 34.4 & $32.8 \mathrm{~b}$ & $43.6 \mathrm{~b}$ & $47.5 \mathrm{ab}$ & $38.0 \mathrm{a}$ & $1.1 \mathrm{~b}$ \\
\hline & SD & 6.3 & 2.6 & 4.4 & 0.3 & 1.6 & 2.8 & 2.6 & 1.5 & 3.6 & 1.9 & 0.1 \\
\hline Significance ${ }^{1}$ & & ns & ns & ns & ** & $* * *$ & ns & ** & $* *$ & * & $* * *$ & $* *$ \\
\hline
\end{tabular}

${ }^{1}$ Significance: $\mathrm{ns}=$ not significant; ${ }^{*},{ }^{* *}$ and ${ }^{* * *}$ significant for $p \leq 0.05,0.01$ and 0.001 , respectively. Different letters indicate statistically significant differences at $p=0.05$.

Table 2. Dry matter, inorganic cations, glucose and fructose content, glucose/fructose ratio, starch and sweetness index of the Regina tomatoes at harvest and after 96 days of storage.

\begin{tabular}{|c|c|c|c|c|c|c|c|c|c|c|c|c|}
\hline \multirow{2}{*}{ Ecotype } & \multirow{2}{*}{$\begin{array}{l}\text { Days of } \\
\text { Storage }\end{array}$} & \multirow{2}{*}{ Value } & Dry Matter & $\mathrm{Na}^{+}$ & $\mathrm{K}^{+}$ & $\mathrm{Ca}^{2+}$ & $\mathrm{Mg}^{2+}$ & Glucose & Fructose & \multirow{2}{*}{$\begin{array}{l}\text { Glu/Fru } \\
\text { Ratio }\end{array}$} & \multirow{2}{*}{$\begin{array}{l}\text { Sweetness } \\
\text { Index }\end{array}$} & \multirow{2}{*}{$\begin{array}{c}\text { Starch } \\
\mathrm{mg} \cdot 100 \mathrm{~g}^{-1} \mathrm{FW}\end{array}$} \\
\hline & & & \multicolumn{2}{|l|}{$\mathrm{g} 100 \mathrm{~g}^{-1} \mathrm{FW}$} & \multicolumn{2}{|c|}{$\mathrm{mg} \cdot \mathrm{kg}^{-1} \mathrm{FW}$} & & \multicolumn{2}{|c|}{$\mathrm{g} \cdot \mathrm{kg}^{-1} \mathrm{FW}$} & & & \\
\hline \multirow{4}{*}{ Monopoli } & \multirow[b]{2}{*}{0} & Mean & $6.24 \mathrm{~d}$ & 164.6 & 2546 & 83.3 & $105.1 \mathrm{~b}$ & 5.9 & 9.0 & 0.66 & 2.7 & 3.5 \\
\hline & & SD & 0.18 & 11.4 & 14 & 22.7 & 3.7 & 1.6 & 2.3 & 0.02 & 0.7 & 0.3 \\
\hline & \multirow[b]{2}{*}{96} & Mean & $6.80 \mathrm{c}$ & 178.9 & 2448 & 86.6 & $108.8 \mathrm{ab}$ & 5.7 & 8.6 & 0.66 & 2.6 & 1.9 \\
\hline & & SD & 0.18 & 26.9 & 114 & 17.7 & 14.2 & 0.5 & 0.7 & 0.01 & 0.2 & 0.1 \\
\hline \multirow{4}{*}{ Fasano } & \multirow[b]{2}{*}{0} & Mean & $7.09 \mathrm{~b}$ & 117.7 & 2838 & 74.1 & $115.5 \mathrm{a}$ & 9.3 & 13.0 & 0.71 & 3.9 & 4.3 \\
\hline & & SD & 0.06 & 15.2 & 89 & 20.8 & 9.0 & 0.2 & 0.3 & 0.01 & 0.1 & 0.5 \\
\hline & \multirow{2}{*}{96} & Mean & $7.28 \mathrm{~b}$ & 132.0 & 2909 & 91.9 & $116.0 \mathrm{a}$ & 6.3 & 8.0 & 0.79 & 2.5 & 2.9 \\
\hline & & SD & 0.07 & 5.0 & 92 & 0.9 & 0.4 & 0.5 & 0.7 & 0.01 & 0.2 & 0.1 \\
\hline \multirow{4}{*}{ Ostuni } & \multirow[b]{2}{*}{0} & Mean & $7.07 \mathrm{~b}$ & 119.3 & 2759 & 108.2 & $100.5 \mathrm{~b}$ & 6.9 & 10.8 & 0.64 & 3.2 & 3.4 \\
\hline & & SD & 0.06 & 6.4 & 173 & 12.4 & 10.1 & 1.1 & 1.5 & 0.01 & 0.4 & 0.5 \\
\hline & \multirow[b]{2}{*}{96} & Mean & $7.66 \mathrm{a}$ & 150.6 & 2966 & 163.6 & 118.3 a & 5.4 & 8.7 & 0.62 & 2.5 & 2.2 \\
\hline & & SD & 0.23 & 18.5 & 74 & 45.8 & 4.1 & 0.9 & 1.2 & 0.02 & 0.4 & 0.1 \\
\hline \multicolumn{13}{|l|}{ Significance $^{1}$} \\
\hline \multicolumn{3}{|l|}{ Ecotype (E) } & $* *$ & * & $* *$ & * & * & $\mathrm{ns}$ & ns & ** & ns & * \\
\hline \multicolumn{3}{|c|}{ Day of storage (D) } & ns & * & ns & ns & * & * & $*$ & ns & $*$ & $* *$ \\
\hline \multicolumn{3}{|c|}{$\mathrm{E} \times \mathrm{D}$} & $* *$ & ns & ns & ns & * & ns & ns & ns & ns & ns \\
\hline
\end{tabular}


Monopoli fruits showed the highest value of $\mathrm{Na}^{+}$and the lowest of $\mathrm{K}^{+}$(Figure 2A,B). As regards $\mathrm{Ca}^{2+}$, Ostuni fruits showed the highest value (Figure 2C), 62\% higher than in Monopoli and Fasano. The $\mathrm{Na}^{+}$content in Monopoli fruits was 32\% higher than in Fasano and Ostuni, whereas the $\mathrm{K}^{+}$content in Fasano and Ostuni fruits was $15 \%$ higher than in Monopoli. This is in agreement to values regarding the inverse relationship between $\mathrm{Na}^{+}$and $\mathrm{K}^{+}$reported by some authors [27,31]. The highest $\mathrm{Na}^{+}$ content in Monopoli fruits is due both to the higher electrical conductivity (EC) of the soil and to the use of brackish water for irrigation. This is due to the proximity of Monopoli fields to the marine coast (Figure 1B), which gives irrigation water extracted from underground (at a depth of 15-20 m), resulting in typically brackish water (EC ranging from 4 to $6 \mathrm{dS} / \mathrm{m}$ ).

A

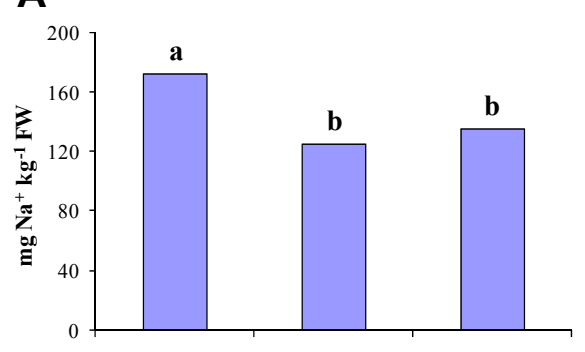

\section{C}

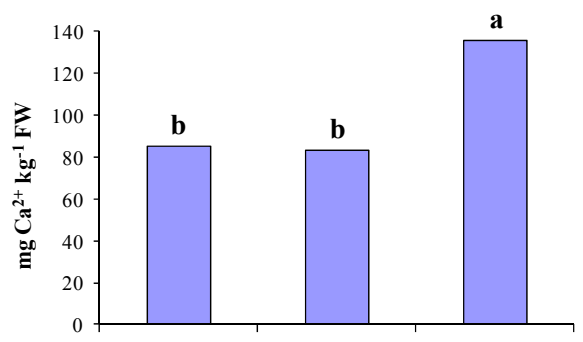

E

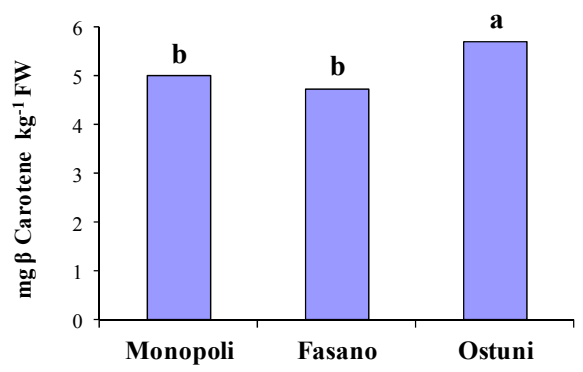

B

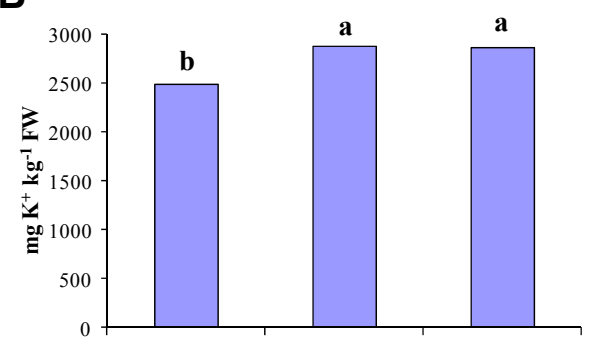

D

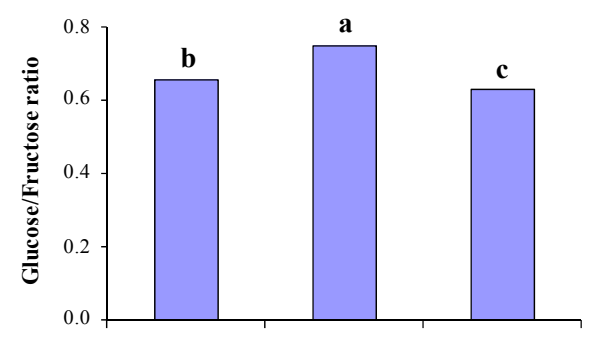

$\mathbf{F}$

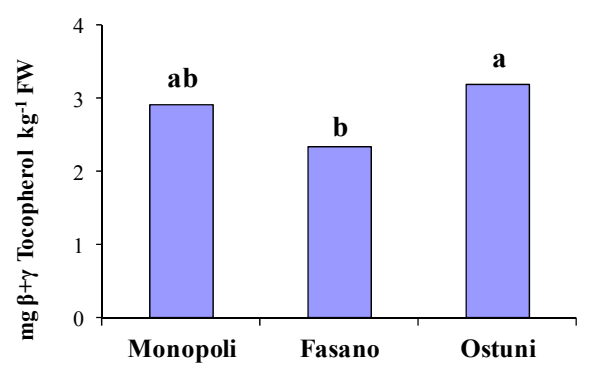

Figure 2. Different Regina tomato traits depending on the ecotype: content of $\mathrm{Na}^{+}(\mathbf{A}), \mathrm{K}^{+}(\mathbf{B}), \mathrm{Ca}^{2+}$ (C); glucose/fructose ratio (D); $\beta$-Carotene content (E); $\beta+\gamma$ Tocopherol content (F). The same letters indicate that mean values are not significantly different $(p=0.05)$.

Sodium plays a vital role in the regulation of fluid balance, blood pressure and transmembrane gradients. However, with the aim to prevent heart diseases attributable to high blood pressure, the European Food Safety Authority recommends a maximum intake of $1500 \mathrm{mg}$ of $\mathrm{Na}^{+}$per day [32]. The results of the present study showed that, independently on the cultivation site, RT fruits may be considered as very low contributors to the daily supply of $\mathrm{Na}^{+}$, since also in the case of RT from Monopoli, $100 \mathrm{~g}$ of fruits supply only about the $1 \%$ of the daily intake. 


\subsection{Sugars, Starch Assay and Sweetness Index}

For both sugars and starch, no significant differences were found for the interaction between ecotypes and storage time (Table 2). The results regarding sugar content showed no significant differences between the three ecotypes with the exception of the glucose/fructose ratio (Table 2). At harvest, the average contents of glucose and fructose in RT fruits were, respectively, 7.35 and $10.90 \mathrm{~g} / \mathrm{kg} \mathrm{FW}$ with a reduction of about $21 \%$ and $23 \%$ after 96 days of storage (Table 2). Regarding starch, the average content at harvest was $3.73 \mathrm{mg} / 100 \mathrm{~g}$ FW with a reduction of about $37 \%$ after 96 days of storage (Table 2). The highest and the lowest glucose/fructose ratio was observed in Fasano and Ostuni fruits, respectively (Figure 2D). The average sweetness index (SI) at harvest was of 3.24, while in RT fruits after a 96-day storage period it was 2.52 (Table 2). These results suggest that the content of reducing sugars (the main tomato carbohydrates) in RT fruits was not influenced by the ecotype, whereas it was affected by the storage time. According to Kader [33] the decrease of glucose and fructose in RT fruits can be due to the respiration process during the long-term storage of fruits. At the same time, the starch content too decreased during long-term storage due to the respiration process of the fruits, but at first converted to the monosaccharides glucose and fructose. It is interesting that in Monopoli fruits, marked starch decrease during long-storage did not correspond to a decrease in reducing sugars (quite stable during storage), while in Fasano fruits a drastic reduction of both starch and monocarbohydrate sugars was observed, even without a significant statistical difference in interaction values (Table 2). In addition, it is interesting to highlight that RT showed a lower average glucose and fructose content compared to other types tomatoes. Effectively, in a study aimed to evaluate six genotypes of long-storage tomatoes, Barbagallo et al. [23] report for glucose a range between 14.4 and $21.5 \mathrm{~g} / \mathrm{kg}$ FW and for fructose a range between 14.7 and $22.0 \mathrm{~g} / \mathrm{kg} \mathrm{FW}$. Moreover, concerning other types of tomatoes such as "cherry tomato", some Authors [23,31] report, respectively, ranges between 15.9 and $25.0 \mathrm{~g} / \mathrm{kg}$ FW for glucose and between 16.4 and $27.0 \mathrm{~g} / \mathrm{kg}$ FW for fructose, in the cultivar Naomi (a diffused commercial variety). As a consequence, a serving size of RT fruits supplies less than the $50 \%$ of the glucose and fructose with respect to other landrace and commercial variety of tomatoes. Thus, RT fruits would be preferred with respect to other types of tomatoes in order to reduce the glycemic load of the meals and, therefore, for reducing elevation in blood insulin associated to an increased risk of type 2 diabetes and coronary heart disease [34]. At the same time, it is important to consider that the lower content of sugars in RT fruits also translates into an SI up to four-fold lower compared to other tomato genotypes [23,31]. Therefore, since the SI is one of the common measures of acceptability of horticultural produce and considering the desire of consumers for sweet tomatoes [35], it is possible that the lower SI of the RT fruits may affect consumers' acceptability.

\subsection{Isoprenoids Content}

RT fruits showed an average lutein content of $5.27 \mathrm{mg} / \mathrm{kg}$ FW without any differences between the three ecotypes, the storage time and their interaction (Table 3). The mean content of $\alpha$ - and $\beta$-Carotene at harvest was, respectively, 0.6 and $5.7 \mathrm{mg} / \mathrm{kg}$ FW with a reduction of about $17 \%$ and $18 \%$ after 96 days of storage (Table 3); no significant differences were found for the interaction between ecotypes and storage time (Table 3). On the other hand, Ostuni fruits showed a $\beta$-Carotene content $17 \%$ higher compared with Monopoli and Fasano (Figure 2E). These results are in agreement with those of other authors $[10,21,36]$ who reported as lycopene is the main tomato carotenoid, while $\alpha$ - and $\beta$-Carotene and lutein are present in low quantities. 
Table 3. Carotenoids, tocopherols and ascorbic acid content of the Regina tomatoes at harvest and after 96 day of storage.

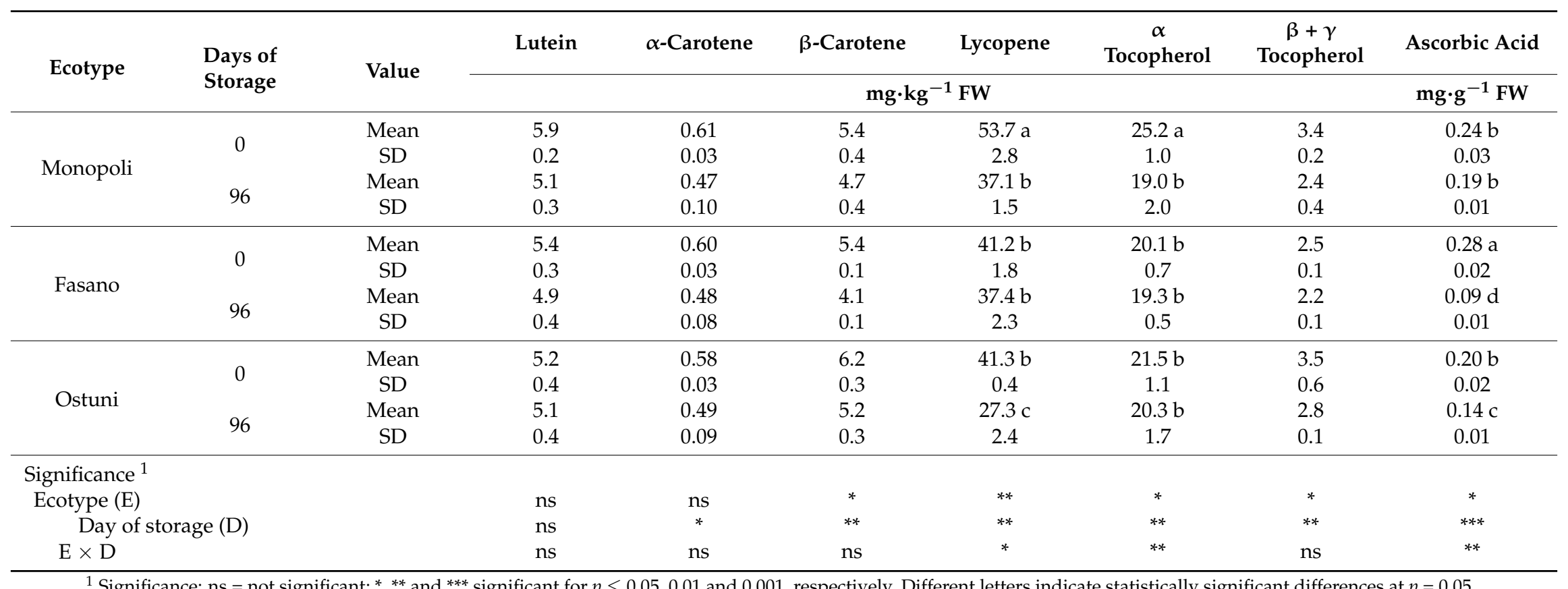

${ }^{1}$ Significance: $\mathrm{ns}=$ not significant; ${ }^{*}, * *$ and ${ }^{* * *}$ significant for $p \leq 0.05,0.01$ and 0.001 , respectively. Different letters indicate statistically significant differences at $p=0.05$. 
As regards lycopene, the highest value was found in Monopoli at harvest, with a reduction of $31 \%$ after 96 days of storage. The storage did not affect the lycopene content in Fasano, while it caused a 34\% reduction in Ostuni (Table 3). Lycopene is responsible for the red colour of tomatoes and is important for human health due to its antioxidant activity. Moreover, dietary intake of tomato lycopene has been shown to be associated with a decreased risk of chronic diseases, such as cancer and cardiovascular disease [21]. The lycopene content of fresh tomato fruits depends on several factors including genotype, environmental growth conditions, cultivation management as well as ripening and phenological stage [21]. Lenucci et al. [37] and Ilahy et al. [38] reported a content of lycopene ranging from 43 to $120 \mathrm{mg} / \mathrm{kg} \mathrm{FW}$ in ordinary tomato cultivars and 175 to $253 \mathrm{mg} / \mathrm{kg}$ FW in high pigment tomato hybrids, grown simultaneously in an open-field of Southern Italy. The results of the present study show that RT fruits can be considered a good source of lycopene even after long-term storage. Indeed, especially for the Monopoli and Fasano fruits, the lycopene content after 3 months of storage was similar to those reported for the cherry tomato cultivar Rubino top (43 mg/ $\mathrm{kg} \mathrm{FW)} \mathrm{[37]}$ and the long storage tomato cultivars Licata (34 mg/ $\mathrm{kg} \mathrm{FW),} \mathrm{Mezzocachi} \mathrm{Montallegro}(38 \mathrm{mg} / \mathrm{kg}$ FW) and Salina 3 (40 mg/kg FW) [10], all grown in Italy. Some other long storage genotypes showed higher lycopene content [10]. As regards the relationship between colour and lycopene content, it is interesting to note that in some cases, deep red varieties of tomatoes (hybrids so-called "high pigment") can contain more than $180 \mathrm{mg} / \mathrm{kg}$ FW [21,37], while some yellow varieties can contain only about $5 \mathrm{mg} / \mathrm{kg}$ FW [39]. Thus, several Authors have reported the correlation between colour indexes of skin tomatoes and lycopene content, also suggesting equations for calculating the lycopene content based on the skin colour readings [24]. According to these authors, the redder the skin colour, the higher the lycopene content in tomato fruits. In the present study the highest lycopene content was found in Monopoli fruits at harvest. Nevertheless, as previously reported, Fasano and Ostuni fruits may be perceived as more "red" than those from Monopoli (Table 1). These results suggest that the external colour of RT fruits is strongly affected by their main morphological traits, especially thick and coriaceus skin, and suggest that for long-storage tomatoes, it may be difficult to find a correlation between skin colour indexes and lycopene content.

\subsection{Tocopherols and Ascorbic Acid Content}

Tomato fruit is an important source of vitamin $E$ which consists of four tocopherols $(\alpha, \beta, \gamma$ and $\delta)$ and four tocotrienols $(\alpha, \beta, \gamma$ and $\delta$ ) and their amount significantly depends on many biotic and abiotic factors. Furthermore, tocotrienols and tocopherols content and composition differ greatly in different plant tissues [21,40]. $\alpha$-Tocopherol $(\alpha-\mathrm{T})$ and $\beta, \gamma$ T-forms (which, in our system, co-migrated as a single peak) were the tocopherol forms detected in RT fruits. $\alpha$-T shows the highest biological activity compared to the other forms and, in this study, at any rate, $\alpha$-T content was even more abundant than the $\beta, \gamma$ T-forms (Table 3). The highest value of $\alpha$-T was found in Monopoli fruits at harvest, with a reduction of about $25 \%$ after 96 days of storage; for Fasano and Ostuni the storage did not affect the $\alpha$-T content (Table 3). The content of $\beta, \gamma$ T-forms of the Ostuni fruits was higher than from Fasano, while no differences were found between Monopoli fruits and all the other ones (Figure 2F). The mean content of $\beta+\gamma$ T-forms at harvest was $3.1 \mathrm{mg} / \mathrm{kg}$ FW with a reduction of about $19 \%$ after 96 days of storage (Table 3). No significant difference was found for the interaction between ecotypes and storage time (Table 3).

In agreement with what was reported by some authors [18,28], the results of the present study highlight that the RT showed a higher tocopherols content with respect to F1 hybrid of tomatoes grown by soilless systems. This could be due to the higher seed content in tomato landraces fruits. In fact, it is known that tomato seeds are a source of tocopherols as reported by some authors [41,42].

Highest and lowest ascorbic acid content were found in Fasano fruits, respectively, at harvest and after 96 days of storage, with a reduction of about $68 \%$. The storage did not affect the ascorbic acid content in Monopoli fruits, while it caused a reduction of 30\% in Fasano and Ostuni fruits (Table 3). These results are in agreement with Soto-Zamora et al. [43] who found a decrease of ascorbic acid 
in tomatoes stored at $4{ }^{\circ} \mathrm{C}$. Ascorbic acid is an essential compound for the human health due to its numerous functions such as prevention of scurvy and maintenance of healthy skin, gums and blood vessels and also because it can reduce the risk of arteriosclerosis, cardiovascular disease and some forms of cancer [44]. The ascorbic acid of fresh tomato fruits is usually about $0.23 \mathrm{mg} / \mathrm{g}$ FW [20] depending on several factors including genotype, environmental grown conditions and cultivation management [21]. In a study aimed to evaluate 12 genotypes tomatoes, George et al. [36] report an average ascorbic acid content of about $0.30 \mathrm{mg} / \mathrm{g}$ FW in cherry tomatoes and a content of about 0.13 $\mathrm{mg} / \mathrm{g}$ FW in other genotypes. Thus, the results of the present study suggest that RT fruits can be considered a good source of ascorbic acid even after long-term storage, especially for the Monopoli fruits. On the other hand, the mean value of ascorbic acid found in 28 long storage tomato genotypes was considerably higher $(0.63 \mathrm{mg} / \mathrm{g} \mathrm{FW})[10]$.

\subsection{Principal Component Analysis}

From PCA results, we can see that PC1 (43.2\%) and PC2 (28.0\%) explain overall 71.1\% of the data variability (Figure 3). PCA allows us to separate distinctly the two storage times along PC1, since data of all ecotypes at storage 0 were positively correlated to $\mathrm{PC} 1$, while those at storage 96 were negatively correlated to the same PC. It is also clear that there is a positive correlation to PC1 of all the organic nutritional parameters which were strongly linked to the fresh status of fruits. On the other hand, $\mathrm{DM}$ and inorganic cations, not modified during storage, were strictly correlated to the stored material. PC2 helps to clearly separate Fasano fruits from those of Monopoli, both at the harvest time. The first are characterized by high soluble sugars, starch and a sweetness index, isolated in the same PCA quadrant, while Monopoli, at harvest, was distinguished by high tocopherol content as well as low sugar content (Figure 3). Other considerations are related to some observations such as Ostuni after storage, correlated to high $\mathrm{Ca}^{2+}$ and $\mathrm{Na}^{+}$content, and Fasano after storage negatively correlated to PC1 due to its low ascorbic acid and $\alpha$-Carotene content (Figure 3).

Biplot (71.12\%)

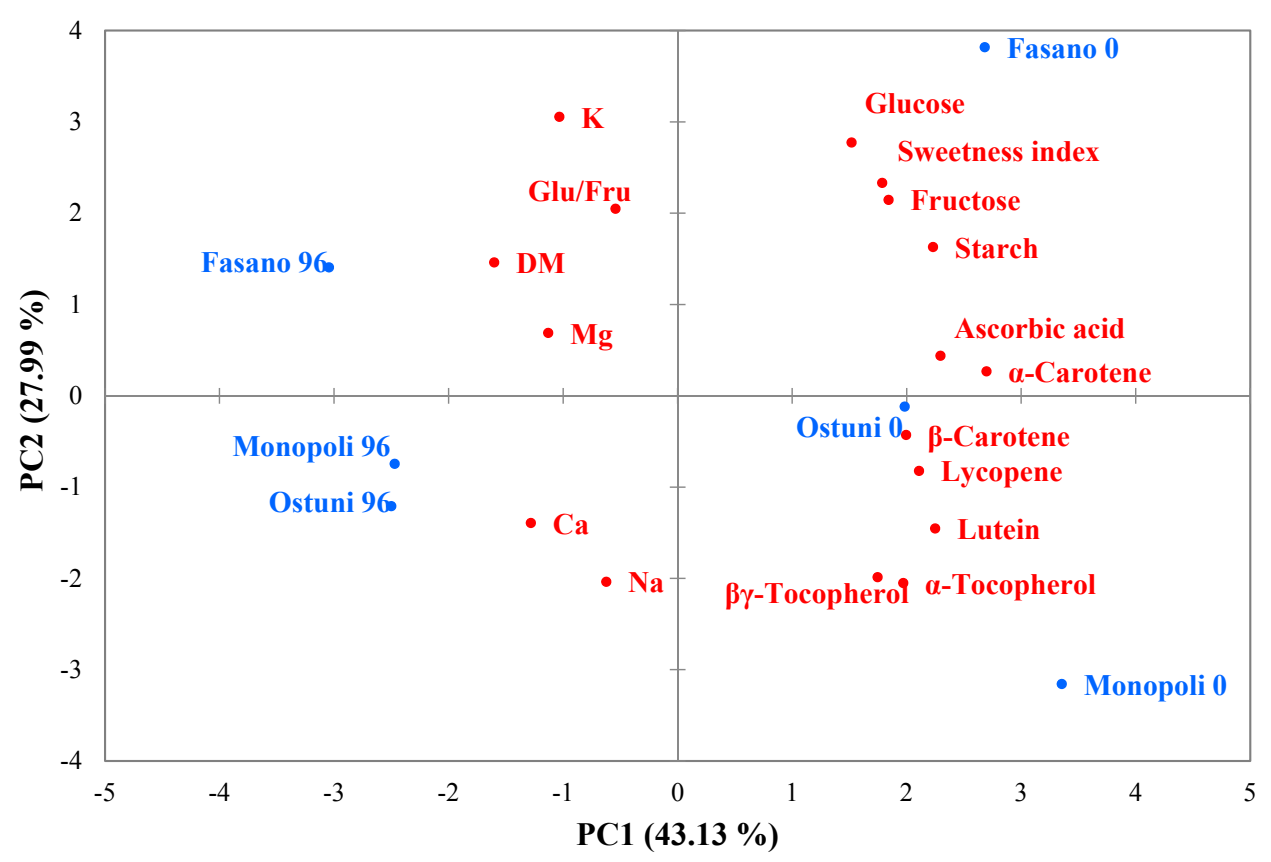

Figure 3. PCA biplot (PC1 vs. PC2) describing the variation of some properties of the three Regina Tomato ecotypes, analysed at harvest (Ecotype 0) and after 96 days of storage (Ecotype 96). 


\section{Conclusions}

Italy is the European country with the largest number of regional origin food products recognized by specific marks such as Protected Designation of Origin and the Protected Geographical Indication. They are assigned by the European Union to those food products that have unique and unmistakable features that depend exclusively, or mainly, on the area where they are produced. In this study, the quality and nutritional assessment of the RT was carried out for highlighting the specific traits of this traditional Italian food product closely linked to the geographic area of origin. Experimental results indicate that this tomato landrace has a qualitative profile that is characterized by high concentrations of tocopherols and a lycopene content similar to values found on average in 28 Italian long storage genotypes. The ascorbic acid, though lower than values found in other Italian tomato landraces, remained quite high even after a long storage time. This profile combined with a lower average glucose and fructose content compared to other types of tomatoes may account for the high nutritional quality of this landrace, especially for people with specific dietary requirements. The results of the present study, enriched by the lacking analysis of the polyphenol content, may be used as a tool for obtaining the PGI or PDO mark, since these results show unique and unmistakable features of this long-storage tomato that depend exclusively on the geographic origin area including both the natural (e.g., climate, environment) and human (e.g., traditional production techniques) factors. Finally, possible next goals may be directed toward non-destructive analytical methods for the rapid determination of nutrients compounds on intact fruits of RT during the long time of storage.

Author Contributions: Conceptualization, M.R. and F.S.; Data curation, M.R., M.D. (Miriana Durante), M.D. (Massimiliano D'Imperio) and F.S.; Formal analysis, M.G.; Funding acquisition, M.R. and F.S.; Investigation, M.R., D.B. and F.S.; Project administration, M.G. and F.S.; Resources, M.R., M.D. (Miriana Durante), M.D. (Massimiliano D'Imperio) and G.M.; Supervision, M.R. and F.S.; Validation, M.R., M.D. (Miriana Durante), M.G., G.M. and F.S.; Visualization, M.R., M.G. and F.S.; Writing_original draft, M.R. and M.G.; Writing-review and editing, M.R., M.D. (Miriana Durante), M.G., D.B., M.D. (Massimiliano D'Imperio), G.M. and F.S.

Funding: This work was supported by Regione Puglia Administration under Rural Development Program 2014-2020 - project 'Biodiversity of vegetable crops in Puglia (BiodiverSO)' and "Intervento cofinanziato dal Fondo di Sviluppo e Coesione 2007-2013-APQ Ricerca Regione Puglia-Programma regionale a sostegno della specializzazione intelligente e della sostenibilità sociale ed ambientale FutureInResearch" — project 'Innovazioni di prodotto e di processo per la valorizzazione della Biodiversità Orticola pugliese (InnoBiOrt)'

Acknowledgments: The authors thank Nicola Gentile and Piero Moretti (Cooperativa Progresso Agricolo) for providing technical assistance during the experiment.

Conflicts of Interest: The authors declare no conflict of interest.

\section{References}

1. Naranjo, R.D.D.P.; Otaiza, S.; Saragusti, A.C.; Baroni, V.; Carranza, A.D.V.; Peralta, I.E.; Valle, E.M.; Carrari, F.; Asis, R. Hydrophilic antioxidants from Andean tomato landraces assessed by their bioactivities in vitro and in vivo. Food Chem. 2016, 206, 146-155. [CrossRef] [PubMed]

2. Baldina, S.; Picarella, M.E.; Troise, A.D.; Pucci, A.; Ruggieri, V.; Ferracane, R.; Barone, A.; Fogliano, V.; Mazzucato, A. Metabolite profiling of Italian tomato landraces with different fruit types. Front. Plant Sci. 2016, 7, 664. [CrossRef] [PubMed]

3. Mazzucato, A.; Ficcadenti, N.; Caioni, M.; Mosconi, P.; Piccinini, E.; Reddy Sanampudi, V.R.; Sestili, S.; Ferrari, V. Genetic diversity and distinctiveness in tomato (Solanum lycopersicum L.) landraces: The Italian case study of "A pera Abruzzese". Sci. Hortic. 2010, 125, 55-62. [CrossRef]

4. Muratore, G.; Licciardello, F.; Maccarone, E. Evaluation of the chemical quality of a new type of small-sized tomato cultivar, the plum tomato (Lycopersicon lycopersicum). Ital. J. Food Sci. 2005, 17, 75-81.

5. Renna, M.; Rinaldi, V.A.; Gonnella, M. The Mediterranean Diet between traditional foods and human health: The culinary example of Puglia (Southern Italy). Int. J. Gastron. Food Sci. 2015, 2, 63-71. [CrossRef]

6. Elia, A.; Santamaria, P. Biodiversity in vegetable crops, a heritage to save: The case of Puglia region. Ital. J. Agron. 2013, 8, 4. [CrossRef] 
7. Slow Food Torre Canne Regina Tomato-Presìdi Slow Food-Slow Food Foundation. Available online: https:/ / www.fondazioneslowfood.com/en/slow-food-presidia/torre-canne-regina-tomato/ (accessed on 3 May 2018).

8. Siracusa, L.; Patanè, C.; Avola, G.; Ruberto, G. Polyphenols as chemotaxonomic markers in Italian "long-storage" tomato genotypes. J. Agric. Food Chem. 2011, 60, 309-314. [CrossRef] [PubMed]

9. Patanè, C.; Pellegrino, A.; Di Silvestro, I. Effects of calcium carbonate application on physiology, yield and quality of field-grown tomatoes in a semi-arid Mediterranean climate. Crop Pasture Sci. 2018, 69, 411-418. [CrossRef]

10. Siracusa, L.; Patanè, C.; Rizzo, V.; Cosentino, S.L.; Ruberto, G. Targeted secondary metabolic and physico-chemical traits analysis to assess genetic variability within a germplasm collection of "long storage" tomatoes. Food Chem. 2018, 244, 275-283. [CrossRef] [PubMed]

11. Naranjo, R.D.D.P.; Otaiza, S.; Saragusti, A.C.; Baroni, V.; Carranza, A.V.; Peralta, I.E.; Valle, E.M.; Carrari, F.; Asis, R. Data on polyphenols and biological activity analyses of an Andean tomato collection and their relationships with tomato traits and geographical origin. Data Brief 2016, 7, 1258-1268. [CrossRef] [PubMed]

12. Figàs, M.R.; Prohens, J.; Raigón, M.D.; Fita, A.; García-Martínez, M.D.; Casanova, C.; Borràs, D.; Plazas, M.; Andújar, I.; Soler, S. Characterization of composition traits related to organoleptic and functional quality for the differentiation, selection and enhancement of local varieties of tomato from different cultivar groups. Food Chem. 2015, 187, 517-524. [CrossRef] [PubMed]

13. López Camelo, A.F.; Gómez, P.A. Comparison of color indexes for tomato ripening. Hortic. Bras. 2004, 22, 534-537. [CrossRef]

14. Sadler, G.; Davis, J.; Dezman, D. Rapid extraction of lycopene and $\beta$-carotene from reconstituted tomato paste and pink grapefruit homogenates. J. Food Sci. 1990, 55, 1460-1461. [CrossRef]

15. Perkins-Veazie, P.; Collins, J.K.; Pair, S.D.; Roberts, W. Lycopene content differs among red-fleshed watermelon cultivars. J. Sci. Food Agric. 2001, 81, 983-987. [CrossRef]

16. Fraser, P.D.; Pinto, M.E.S.; Holloway, D.E.; Bramley, P.M. Application of high-performance liquid chromatography with photodiode array detection to the metabolic profiling of plant isoprenoids. Plant J. 2008, 24, 551-558. [CrossRef]

17. Ferreira, I.C.F.R.; Aires, E.; Barreira, J.C.M.; Estevinho, L.M. Antioxidant activity of Portuguese honey samples: Different contributions of the entire honey and phenolic extract. Food Chem. 2009, 114, 1438-1443. [CrossRef]

18. Caretto, S.; Parente, A.; Serio, F.; Santamaria, P. Influence of potassium and genotype on vitamin E content and reducing sugar of tomato fruits. HortScience 2008, 43, 2048-2051.

19. Crespo, P.; Bordonaba, J.G.; Terry, L.A.; Carlen, C. Characterisation of major taste and health-related compounds of four strawberry genotypes grown at different Swiss production sites. Food Chem. 2010, 122, 16-24. [CrossRef]

20. D'Imperio, M.; Renna, M.; Cardinali, A.; Buttaro, D.; Serio, F.; Santamaria, P. Calcium biofortification and bioaccessibility in soilless "baby leaf" vegetable production. Food Chem. 2016, 213, 149-156. [CrossRef] [PubMed]

21. Serio, F.; Ayala, O.; Bonasia, A.; Santamaria, P. Antioxidant properties and health benefits of tomato. In Progress in Medicinal Plants—Search for Natural Drugs; Studium Press LLC: Houston, TX, USA, 2006; Volume 13, pp. 159-179, ISBN 9780976184959.

22. Siracusa, L.; Avola, G.; Patanè, C.; Riggi, E.; Ruberto, G. Re-evaluation of traditional Mediterranean foods. The local landraces of "Cipolla di Giarratana" (Allium cepa L.) and long-storage tomato (Lycopersicon esculentum L.): Quality traits and polyphenol content. J. Sci. Food Agric. 2013, 93, 3512-3519. [CrossRef] [PubMed]

23. Barbagallo, R.N.; Chisari, M.; Branca, F.; Spagna, G. Pectin methylesterase, polyphenol oxidase and physicochemical properties of typical long-storage cherry tomatoes cultivated under water stress regime. J. Sci. Food Agric. 2008, 88, 389-396. [CrossRef]

24. Arias, R.; Lee, T.C.; Logendra, L.; Janes, H. Correlation of lycopene measured by HPLC with the $L^{*}, a^{*}, b^{*}$ color readings of a hydroponic tomato and the relationship of maturity with color and lycopene content. J. Agric. Food Chem. 2000, 48, 1697-1702. [CrossRef] [PubMed]

25. Yahia, E.M.; Brecht, J. Tomatoes. In Crop Post-Harvest: Science and Technology: Perishables; Rees, D., Farrell, G.O.J., Eds.; Wiley-Blackwell: Oxford, UK, 2012; pp. 5-23, ISBN 0632057254. 
26. Elia, A.; Santamaria, P.; Colelli, G.; De Boni, A.; Ventrella, D.; Serio, F. Produzione, qualità e attitudine alla conservazione di popolazioni di pomodoro da serbo. Risultati preliminari. In Atti Giornate Scientifiche SOI; Società Orticola Italiana: Sesto Fiorentino, Italy, 1992; pp. 406-407.

27. Serio, F.; De Gara, L.; Caretto, S.; Leo, L.; Santamaria, P. Influence of an increased NaCl concentration on yield and quality of cherry tomato grown in posidonia (Posidonia oceanica L. Delile). J. Sci. Food Agric. 2004, 84, 1885-1890. [CrossRef]

28. Nielsen, F.H. Trace mineral deficiencies. In Handbook of Nutrition and Food; CRC Press, Taylor \& Francis: Boca Raton, FL, USA, 2008; pp. 159-176. ISBN 9781420008890.

29. Chapagain, B.P.; Wiesman, Z. Effect of potassium magnesium chloride in the fertigation solution as partial source of potassium on growth, yield and quality of greenhouse tomato. Sci. Hortic. 2004, 99, 279-288. [CrossRef]

30. USDA Food Composition Databases Show Foods-Tomatoes, Red, Ripe, Raw, Year Round Average. Available online: https://ndb.nal.usda.gov/ndb/foods/show /302115? manu=\&fgcd=\&ds=SR\& q=Tomatoes, red,ripe,raw, yearroundaverage (accessed on 3 May 2018).

31. Elia, A.; Serio, F.; Parente, A.; Santamaria, P.; Ruiz Rodriguez, G. Electrical conductivity of nutrient solution, plant growth and fruit quality of soilless grown tomato. Acta Hortic. 2001, 503-508. [CrossRef]

32. European Food Safety Authority Tolerable Upper Intake Levels for Vitamins and Minerals. Available online: http:/ / www.efsa.europa.eu/sites/default/files/efsa_rep/blobserver_assets/ndatolerableuil.pdf (accessed on 3 May 2018).

33. Kader, A.A. Flavor quality of fruits and vegetables. J. Sci. Food Agric. 2008, 88, 1863-1868. [CrossRef]

34. Bornet, F.R.; Costagliola, D.; Rizkalla, S.W.; Blayo, A.; Fontvieille, A.M.; Haardt, M.J.; Letanoux, M.; Tchobroutsky, G.; Slama, G. Insulinemic and glycemic indexes of six starch-rich foods taken alone and in a mixed meal by type 2 diabetics. Am. J. Clin. Nutr. 1987, 45, 588-595. [CrossRef] [PubMed]

35. Beckles, D.M. Factors affecting the postharvest soluble solids and sugar content of tomato (Solanum lycopersicum L.) fruit. Postharvest Biol. Technol. 2012, 63, 129-140. [CrossRef]

36. George, B.; Kaur, C.; Khurdiya, D.S.; Kapoor, H.C. Antioxidants in tomato (Lycopersium esculentum) as a function of genotype. Food Chem. 2004, 84, 45-51. [CrossRef]

37. Lenucci, M.S.; Caccioppola, A.; Durante, M.; Serrone, L.; De Caroli, M.; Piro, G.; Dalessandro, G. Carotenoid content during tomato (Solanum lycopersicum L.) fruit ripening in traditional and high-pigment cultivars. Ital. J. Food Sci. 2009, 21, 461-472.

38. Ilahy, R.; Hdider, C.; Lenucci, M.S.; Tlili, I.; Dalessandro, G. Antioxidant activity and bioactive compound changes during fruit ripening of high-lycopene tomato cultivars. J. Food Compos. Anal. 2011, 24, 588-595. [CrossRef]

39. Hart, D.J.; Scott, K.J. Development and evaluation of an HPLC method for the analysis of carotenoids in foods, and the measurement of the carotenoid content of vegetables and fruits commonly consumed in the UK. Food Chem. 1995, 54, 101-111. [CrossRef]

40. Raiola, A.; Tenore, G.; Barone, A.; Frusciante, L.; Rigano, M. Vitamin E content and composition in tomato fruits: Beneficial roles and bio-fortification. Int. J. Mol. Sci. 2015, 16, 29250-29264. [CrossRef] [PubMed]

41. Seybold, C.; Frohlich, K.; Bitsch, R.; Otto, K.B.V. Changes in contents of carotenoids and vitamin E during tomato processing. J. Agric. Food Chem. 2004, 5, 7005-7010. [CrossRef] [PubMed]

42. Durante, M.; Montefusco, A.; Marrese, P.P.; Soccio, M.; Pastore, D.; Piro, G.; Mita, G.; Lenucci, M.S. Seeds of pomegranate, tomato and grapes: An underestimated source of natural bioactive molecules and antioxidants from agri-food by-products. J. Food Compos. Anal. 2017, 63, 65-72. [CrossRef]

43. Soto-Zamora, G.; Yahia, E.M.; Brecht, J.K.; Gardea, A. Effects of postharvest hot air treatments on the quality and antioxidant levels in tomato fruit. LWT-Food Sci. Technol. 2005, 38, 657-663. [CrossRef]

44. Harris, J.R. Ascorbic Acid: Biochemistry and Biomedical Cell Biology; Plenum Press: New York, NY, USA, 1996; ISBN 1461303257.

(C) 2018 by the authors. Licensee MDPI, Basel, Switzerland. This article is an open access article distributed under the terms and conditions of the Creative Commons Attribution (CC BY) license (http:/ / creativecommons.org/licenses/by/4.0/). 